\title{
Rebels with a Cause: The Spiritual Dimension of Social Marketing
}

\begin{tabular}{|r|l|}
\hline Journal: & Journal of Social Marketing \\
\hline Manuscript ID & JSOCM-02-2017-0010 \\
\hline Manuscript Type: & Conceptual Paper \\
\hline Keywords: & Social marketing, Spirituality, Health promotion, Marketing \\
\hline \multicolumn{2}{|l}{} \\
\hline
\end{tabular}

SCHOLARONE ${ }^{m}$

Manuscripts 


\title{
Rebels with a Cause: The Spiritual Dimension of Social Marketing
}

\author{
Professor Gerard Hastings \\ The Institute for Social Marketing \\ University of Stirling, the Open University \\ and L'École des Hautes Etudes en Santé Publique \\ Stirling FK9 4LA \\ SCOTLAND
}


Abstract

Purpose: To explore the spiritual dimension of social marketing.

Approach: Conceptual

Findings: The greatest problems humankind faces, from NCD epidemics to global warming, are selfinflicted. We are voluntarily drinking the sugar sweetened beverages and driving the SUVs which threaten our health and our planet. It need not be so. Historical experience and two millennia of thinking show we are capable of better. We all have within us the moral agency to make the right choice even when it is the difficult one; we just have to reconnect with it. Indeed, it is this capacity and desire "to follow after wisdom and virtue", to rebel against injustice and malignancy, that makes us human and cements our collective identity. In the last century this realisation was focused by the terrible events of World War II and resulted in the formation of the United Nations and the Universal Declaration of Human Rights.

Originality/value: This paper argues that these ideas of agency, morality and rights have fundamental implications for social marketing. We have to move beyond mere behaviour change and start thinking about people in the round - body, mind and spirit. Our job involves more than giving diets a healthy nudge or making the ecological option easy, fun and popular; we have to foster and encourage the innate human drive to think critically and act accordingly. We are not here to edit choice but to facilitate personal growth and social progress.

\section{Introduction: self-harm on an industrial scale}

In the WHO European region $88 \%$ of deaths are now caused by non-communicable diseases such as diabetes, cancer and heart disease (WHO 2016). In the public health literature, these illnesses have become known as 'industrial epidemics', because they are driven by commerce, and specifically the overbearing marketing of alcohol, tobacco and highly processed foods. Furthermore there is compelling evidence that marketing does have exactly this kind of morbid power, especially over young people (Lovato et al 2003, Anderson et al 2009, Cairns et al 2009).

However an alternative conception of what is happening is that this carnage is self-inflicted; we are damaging and killing ourselves with our own consumption behaviour. Notwithstanding Coke's $\$ 3.3$ billion annual adspend (WARC 2016), we are not forced to drink its sugary beverages; Diageo's multimillion pound link-up with Facebook (Bradshaw 2011) does not prevent us from saying no to alcopops. Yes there is a massive power imbalance, and yes such unhealthy marketing needs to be contained, but nonetheless we do have a choice. We are capable of thinking for ourselves. And yet it seems we are happy to accept our fate without demur and collaborate in our own destruction.

Our lemming-like tendencies extend beyond lifestyle diseases; we are collaborating in the destruction of our communities with equal enthusiasm. It is easy to blame big box retailers for stifling the social capital of small shops or the car industry for our choked and polluting roads, but their success is completely dependent on our patronage. This we enthusiastically provide; we don't just shop at Tesco and Walmart, we willingly indenture ourselves with their loyalty schemes. Tesco's Club card programme, for example has over 16 million active members in the UK; its rival Sainsbury has over 19 million (Express 2016). The dictionary definition of loyalty is "a feeling of devotion, duty, 
or attachment to somebody"; it is unnerving that we use such a word to describe our relationship with a multinational corporation. Nor do SUVs drive themselves. We have freely bought into the conceit that we need a ton of metal with the technical capacity to cross the Sahara to get us a few hundred metres to the object of our retail devotion. Our behaviour doesn't even make economic sense: we willingly get ourselves into debt in our haste to kowtow to our materialist emperors (Guardian 2016).

Our self-harming collaboration takes its most troubling form with anthropomorphic climate change. This has been dubbed a 'wicked problem' because of its apparent complexity. But in at least one sense it is actually very simple. Anthropomorphic, of course, means caused by humans; in other words us. In particular, those of us who are in the wealthiest $20 \%$ of the world's population whose shopping behaviour is so utterly unsustainable. Planetary degradation is, in reality, just another lifestyle illness; one more symptom of our unthinking collaboration, our perpetual adoption of the line of least resistance. As the environmentalist George Monbiot observes "We'd never dream of killing gorillas or sharks, but let others do it: extinction is the bycatch of consumerism". We manage to live comfortably with these double standards; he continues: "it's not ignorance that's wiping out so many species: it's our naked hypocrisy". We also manage to live comfortably with planetary degradation; a week after Monbiot filed his piece, the World Meteorological Organisation's (WMO) annual greenhouse gas bulletin revealed that "globally averaged concentration of carbon dioxide in the atmosphere" had "reached the symbolic and significant milestone of 400 parts per million for the first time". This, the UN body warned, marked "the start of a new era of climate reality" (WMO 2016). A reality we blithely deny as we continue our consumerist collaboration.

\section{Learning from the abolitionists}

It was not always so. William Wilberforce is often given the credit for the abolition of slavery, and there is no doubt that he and his colleagues do deserve a lot of credit. However the true heroes of the hour were people like us; ordinary citizens. Wilberforce himself recognised that nothing would be achieved without public support and in his famous speech to the House of Commons he called on the British citizenry with the ringing phrase: "we ought all to plead guilty" (Smith 2012), invoking both the moral and practical imperative of grass roots involvement.

The challenge was truly daunting. In 1787 , when the campaign began, there were actually more slaves than free people in the world. Furthermore, slavery represented massive economic interests: in the UK with its growing Empire, nearly 2\% of Gross Domestic Product was at stake. Wilberforce and his eight colleagues used many techniques modern social marketers would recognise. They had a clear vision, 'drawing connections between the near and the distant', for what they wanted to achieve. This was converted into achievable, pragmatic objectives - the cessation of trading rather than complete emancipation (the former would inevitably lead to the latter anyway). They engaged in classic strategic planning based on careful market research, a detailed situation analysis identifying key stakeholders and competitors and shrewd tactical deliberation. They recognised that success would take time (eight of the nine originators were dead by the time their aim was accomplished) and hence progress needed continuous monitoring to inform adjustments to the strategy. Mass media communications were also deployed to great effect, and in the best social marketing traditions, they weren't afraid to use highly emotional appeals (Fig 1). 
"A woman was one day brought to us to be sold; she came with a child in her arms. The captain refused to purchase her on that account, not wishing to be plagued with a child on board; in consequence of that she was taken back to the shore. On the following morning, however, she was again brought to us, but without the child, and she was apparently in great sorrow. The black trader who brought her on board said that the child had been killed in the night to accommodate us in the sale." (Smith op cit)

But the most important factor in their success was the vital role played by ordinary people. Abolition movements were established in towns across the country. These encouraged critical thinking drawing "the dramatic, direct connection between British daily life and that of slaves". Tea, that quintessentially British symbol of civilised domesticity, became "the blood stained beverage". This critical thinking was converted into direct action - fundraising, letter writing to political representatives, petitions, protests, fliers, public meetings and boycotts of sugar and tea. The result was an unstoppable force and, despite the special pleading and massive commercial interests, the government simply had to move. A leading newspaper of the time expressed it trenchantly: "the sense of the people has pressed abolition on our rulers".

\section{Moral agency}

The abolitionists reveal something fundamental about human beings: we have the ability to think through the implications of our actions, to distinguish between right and wrong and to act accordingly. We can plan for the future; forgo benefits today for rewards tomorrow. We can also think of others. We are capable of altruism, of putting ourselves in harm's way for the benefit of our fellow beings. Parents habitually make sacrifices for their children; soldiers are honoured for risking their own safety to protect their comrades. As a recent newspaper editorial argued, these are uniquely human qualities: "We are the only species capable of reflecting on our impact. We have moral agency. We can foresee the likely consequences of our actions, consider them, and then make choices" (Guardian 2016). We are, in the words of the poet, the masters of our fate and the captains of our soul (Henley).

Sadly, good parents and heroic warriors notwithstanding, this moral agency seems to be in short supply. Lifestyle diseases, over consumption and especially our disregard for the environment betray a disturbing lack of principled analysis, consideration for others or thought for the future. The leader continues: "In relation to the environment, these choices have frequently been wrong and show little sign of being right in time to save us from very large and damaging climate change."

This suggests that a crucial task for social marketing is to reawaken our moral agency. Perhaps instead of addressing 'wicked problems' like obesity or global warming with complex systems thinking, accompanied by daunting Foresight diagrams, we should be looking internally to the human qualities that enable us to feel as well as think, to consider morality in addition to convenience and to do the right thing not because it is easy, fun and popular but because it is right.

Indeed if we consider for a moment the complexity of the relationship between behaviour and welfare, anything else seems naïve. Yes we know of the link between tobacco and lung cancer, so encouraging people to avoid or quit smoking makes obvious sense. The same type of evidence and thinking applies for alcohol and ultra-processed foods. We can stretch this further to energy efficiency, recycling, public transport... but life is so much more than a collection of behaviours. The forces which make us happy, or feel fulfilled or give us purpose cannot be identified and proven 
effective by an RCT or delivered by an intervention. To a large extent they are not external at all, but lie inside each of us.

In this sense moral agency becomes much more than a handy strategic tool. When Pandora let human vices escape her box, moral agency was the driving force of the hope that struggled out in their wake. It tells us something about the nature of our humanity. Nowhere is this more apparent than in the consideration of climate change, because it requires us to think about the future; about the world after our deaths; about a time and place where personal gain is no longer possible, and more profound issues assert themselves. The recent Papal Encyclical spells out the implications: "When we ask ourselves what kind of world we want to leave behind, we think in the first place of its general direction, its meaning and its values..... if those issues are courageously faced, we are led inexorably to ask other pointed questions. What is the purpose of our life in this world? Why are we here? What is the goal of our work and all our efforts? What need does the earth have of us? It is no longer enough, then, simply to state that we should be concerned for future generations. We need to see that what is at stake is our own dignity. Leaving an inhabitable planet to future generations is, first and foremost, up to us" (Laudato Si, 2015).

The word dignity is crucial here. The dictionary links it to self-respect and a sense of personal pride. Thus it begins to explain why agency is so important; it suggests a fundamental human need to exercise judgement and make choices, even when these are difficult. The key benefit of doing this is self-enhancement: we learn how to make challenging decisions, with practice we get better at doing it and as a result we become more rounded human beings. In Charles Bukowski's (1996) words "the more you learn to do it the more light there will be".

Farid at din Attar (1974), an eminent Sufi scholar came to the same conclusion almost a millennium ago. Figure 2 summarises his epic poem the Conference of the Birds which tells of our hunt for spiritual purpose, a sense of meaning beyond the everyday priorities that tend to dominate our lives.

\section{Figure 2: The Conference of the Birds}

The birds of the air were anxious; they felt in urgent need of advice and leadership. A great conference was organised where they came together to discuss what might be done. The Hoopoe spoke up and persuaded the gathering that they needed to go in search of the Simurgh or spiritual leader, to provide them with the direction they lacked. After much debate and multiple attempts by different birds to avoid going on what would be an arduous journey, the quest got underway. It took many difficult years and involved crossing the seven valleys - of searching, love, understanding, friendship, unity, amazement, and death - each presenting its own challenges and lessons. As the pilgrimage proceeded, many birds abandoned the journey or were overcome by the ordeals they encountered. Eventually, now depleted to band of just thirty, they arrived at a marvellous palace, which, the Hoopoe explained, was the home of the Simurgh. At first the palace guard would not let what had become a raggedy and disreputable looking gang enter the great mansion; but after a struggle they were admitted. Inside they searched everywhere for the Simurgh but the place was empty. All they found was wall after wall lined with mirrors of every size and shape.

It was in these that they at last caught sight of their spiritual leaders.

Like Bukowski he is advising us to look inwards. Such introspection undoubtedly brings with it the need for effort: it is arduous and it is 'up to us'. It is also an endless task; "the search for meaning is itself the meaning" Foley M (2010). But, it is essential to our humanity: "the man who lives and does 
not strive is lost" (ibid). It also suggests a more adult and humane approach to social progress than the thoughtless behaviour change orchestrated by nudge.

\section{If this is a Man}

If our behaviour is not simply a function of external stimulus, let alone well-meaning interventions, but also a product of our internal qualities, we have to understand more about what these are, about what it is to be human. Primo Levi, the holocaust survivor, saw Auschwitz as an appalling but brutally effective experiment which was, inadvertently, capable of answering this question. In his book, If this is a Man, he explains how the Nazis set about systematically dehumanising their victims so as to make it easier to mistreat and murder them. Life in the camps was deliberately designed to be as unbearable as possible so prisoners were pushed to behave selfishly, even brutally - to emulate their oppressors and abandon their humanity - in order simply to survive. And they were utterly defenceless: "we are slaves, deprived of every right, exposed to every insult, condemned to certain death..." Never had external stimuli been more destructive or debilitating, yet Levi maintains that the prisoners still possessed a vital level of agency: "...but we still possess one power, and we must defend it with all our strength for it is the last - the power to refuse our consent" (Levi P 1979). However desperate our plight, we have an inner room which we can and must save from violation. This is our dignity. For Levi it is what makes us human.

Later in the book he takes this thinking a step further, using Dante's Divine Comedy. In his poem, Dante invokes Vergil and the epic journey of Ulysses. Specifically Levi quotes a speech the Greek hero made to embolden his men for the next stage of their voyage.

"Look inward, to your origins. For brutish ignorance

Your mettle was not made; you were made human

To follow after wisdom and virtue" (Dante)

The words have a profound effect on his men and they become more than willing to continue their "foolhardy journey beyond the Pillars of Hercules" (symbolising the dangerous unknown) (Levi, op cit) because it offered the promise of wisdom. The power of the words was not a tribute to Ulysses' oratory, but confirmation that he was appealing to their irreducible humanity. Beings of their - our - mettle could do no other. Thus the same two principles emerge: our lot as human beings is to be seekers after wisdom and virtue; this quest will not be easy - it requires effort, hard work, the overcoming of adversity. Dante understood adversity as well as did Ulysses and his crew; he wrote his Divine Comedy as an exile on the run from the powerful political factions of medieval Italy.

But living in a consumer society like ours obscures the benefits of striving. Obstacles become new product development opportunities and shopping the means of assuaging them. It is difficult to embrace toil and adversity when the dominant narrative is of customer service and perpetual satisfaction. Critical social marketing has a key role to play in deconstructing this damaging narrative.

\section{Transcendence}

Aldous Huxley extends this thinking when he talks of an innate human drive for 'self-transcendence', adding a rather chilling reminder that this is an immensely powerful urge because humankind's selfknowledge - and particularly the realisation of our own mortality - underpins a compulsion "to escape from the tormenting consciousness of being merely ourselves" (Huxley 1971). We are continually seeking a sense of purpose to our lives. But again he warns that it is dependent on adversity; there are no simple solutions: self-transcendence takes hard work. Consequently, as 
Huxley goes on to discuss, this drive is extraordinarily susceptible to corruption. We are all reluctant "to take the hard, ascending way" and instead opt for "bogus liberation". Marketing, with its excellent, 'because you're worth it', service, with its siren call to consume ourselves to happiness, is bogus liberation writ large. Social marketing risks falling into the trap of copying this infantilising approach when it resorts to spoon-feeding and nudging.

More recent writers in the field of technology also express concerns about what they term 'solutionism' (Morozov 2013); IT being used to solve problems for us that we don't even know exist. This inures us from the consequences of our acts: my smart phone provides a service that my parents could barely have imagined and in the process suppresses my nagging concerns about the conflict minerals it contains. It also spoils us; we very rapidly demand more and more functionality. Comedian Louis C.K. (2016) does a riff on how quickly we take remarkable innovations - from human flight to mobile phones - for granted. He concludes, with brutal honesty: 'we live in an amazing, amazing world and it's wasted on the crappiest generation of, just, spoiled idiots that don't care'. Morozov adds a third corrosive impact of solutionism: we learn to react rather than respond: 'treating issues as puzzles to which there is a solution, rather than problems to which there may be a response' (Morozov op cit). Michael Sandel (2013) reminds us of the long term dangers: "altruism, generosity, solidarity and civic spirit are not like commodities that are depleted with use. They are more like muscles that develop and grow stronger with exercise."

And so the individual can be seen as the indivisible unit and motive force of social change. A key task of social marketing is to stimulate and empower this force. This takes us much deeper than mere behaviour change. It calls for humility to admit we do not have all the answers; a recognition that solutionism can do more harm than good; that we should not be seeking obedience but encouraging disobedience (Hastings 2015). The self-destructive collaboration that is driving both non-communicable disease and global warming is most vulnerable to critical awareness. For social marketers it raises the question of whether we should be concerned with behaviour or with people. Dante, Levi and Huxley would put the question more bluntly: is social marketing here to enhance our humanity or just further encourage its decline?

\section{Collective agency and human rights}

Thus a focus on the individual is not to deny the importance of the collective, but to reinforce it. Once we start to look critically at our world, it pushes us to consider others. If I am unhappy with the effects the system is having on me, at the same instant I come to recognise that others are also suffering. If my father dies of pneumoconiosis I begin to empathise with the fate of other coal miners or if a car knocks me off my bike the benefits of cycle paths for all become more apparent. French writer Albert Camus is precise about this, arguing that whilst our suffering in the face of a world that is difficult to understand and often unsympathetic (in his words 'absurd') is individual, once we begin to criticise and act on these criticisms - that is to rebel - it immediately becomes collective. The stimulus to mitigate our individual hardship connects us with the humanity of others; the individual harm becomes a shared plague. Much as Descartes argued that our desire and ability to think demonstrates our individual existence, so Camus sees our desire and ability to rebel as proof of our collective existence. 'I think therefore I am' is joined by 'I rebel therefore we are' (Camus 2015).

Camus and Levi were writing in the immediate aftermath of the Second World War; a time when it was recognised that there had been a profound failure of moral agency and there was a desperate 
hunger to prevent any repetition of the holocaust and its related horrors. In this context, the idea that all human beings have the same fundamental qualities, share an "inherent dignity", and are equal "members of the human family" had powerful resonance. The idea grew that the protection and nurturing of these qualities, and recognition of them as inalienable moral and legal rights was the only progressive way forward. Under the auspices of the newly formed United Nations this resulted in The Universal Declaration of Human Rights.

Its implications for social marketing are fundamental. Take for example the Convention on the Rights of the Child (Fig 3) which is the most widely-ratified international treaty in history. It enshrines in international law "the right of the child to the enjoyment of the highest attainable standard of health", that for any government "the best interests of the child shall be a primary consideration" and requiring administrations "to ensure the child such protection and care as is necessary for his or her well-being, ....and, to this end, shall take all appropriate legislative and administrative measures". This means that measures social marketers would support, such as controls on harmful marketing or minimum unit pricing are not just evidence-based actions which governments can be encouraged to take, they are legal obligations which they have to take. It also challenges treasured assumptions. The idea that interventions necessarily threaten freedom, for example, as the Nuffield Ladder of Interventions (Nuffield Council on Bioethics 2007) presupposes, become much more questionable. The supposedly oppressive influence of the 'nanny state' is likewise undermined when we consider that children have a right to protective legislation. Indeed it completely inverts the argument, suggesting that the overbearing nanny is actually the unhealthy marketer, not the legislator, and she is a nanny from hell.

Article 3

1. In all actions concerning children, whether undertaken by public or private social welfare institutions, courts of law, administrative authorities or legislative bodies, the best interests of the child shall be a primary consideration.

2. States Parties undertake to ensure the child such protection and care as is necessary for his or her wellbeing, taking into account the rights and duties of his or her parents, legal guardians, or other individuals legally responsible for him or her, and, to this end, shall take all appropriate legislative and administrative measures.

3. States Parties shall ensure that the institutions, services and facilities responsible for the care or protection of children shall conform with the standards established by competent authorities, particularly in the areas of safety, health, in the number and suitability of their staff, as well as competent supervision.

\section{Article 24}

1. States Parties recognize the right of the child to the enjoyment of the highest attainable standard of health and to facilities for the treatment of illness and rehabilitation of health. States Parties shall strive to ensure that no child is deprived of his or her right of access to such health care services.

2. States Parties shall pursue full implementation of this right and, in particular, shall take appropriate measures:

a) To diminish infant and child mortality;

b) To ensure the provision of necessary medical assistance and health care to all children with emphasis on the development of primary health care;

c) To combat disease and malnutrition, including within the framework of primary health care, through, inter alia, the application of readily available technology and through the provision of adequate nutritious foods and clean drinking-water, taking into consideration the dangers and risks of environmental pollution;

d) To ensure appropriate pre-natal and post-natal health care for mothers;

e) To ensure that all segments of society, in particular parents and children, are informed, have access 

advantages of breastfeeding, hygiene and environmental sanitation and the prevention of accidents;

f) To develop preventive health care, guidance for parents and family planning education and services.

But the implications of human rights for social marketing take us beyond advocacy. They reinforce the importance of moral agency: "the nature that underlies natural or human rights is the moral nature of a human being" and they emphasise the idea of human potential "human rights are less about the way people are than about what they might become" (Donnelly 1985). Human rights law can provide an environment in which this potential can be fulfilled, but in and of itself will not stimulate people to take up the resulting opportunities for personal growth. Social marketing has a vital role to play in providing this stimulus; in providing society with a critical and aware citizenry that will make the most of its hard-earned and mandated human rights. Young people can, for example, be encouraged to exert their rights to protection from tobacco industry predation, as they were with the American Legacy's Truth Campaign (Farrelly et al 2002), and more recently in Cancer Research UK's “Smoke This” and “Make Them Pay” digital initiatives (CRUK 2016).

The prize for doing this is indeed worth the winning: "...human development is possible only through comprehensive human action coordinated by human rights". However it carries with it risks as well benefits: "The 'human nature' that underlies human rights is quintessentially human, full of frailties but also fraught with the possibility of the greatest glory. Human rights are a practical political institution for widely realising these higher potentials..." (Donnelly op cit). If social marketers are going to move from micromanaging specific behaviours to empowering people, they have to be prepared to let go control and take chances. This is not as radical as it might sound; arguably it is just the natural endpoint for the social marketing commitment to client orientation. If we listen to and respect the people we work with to the extent that we claim, we should have the confidence to trust them with finding their own solutions. Or as the liberation theologist argued: "it is not about giving them a fish; it is not even about teaching them to fish - it is about recognising their ownership of the river" (Codina 1985).

Conversely popular engagement in this field is also an important safety measure. Without it, human rights legislation risks becoming no more than pious sentiment, or worse doing actual harm. Vanessa Pupavac (2002), for example explains how over-zealous application by adults of the child's right to safety has dangerously constrained play, reducing school playtimes and even eliminating unsupervised play altogether: "Panics over strangers, concerns about environmental dangers, potential litigation over accidents (however remote) and fears over bullying are all leading to a constriction of children's play. The expanded meaning of protecting children from harm has required such all-encompassing dimensions that the eradication of risk effectively entails the elimination of unsupervised play". The negative consequences included isolation, obesity and mental illness. The way to prevent this unintended harm is to encourage everyone to join the debate; social marketers, along with others interested in progressive social change, need to embrace this challenge.

\section{Conclusion}

We are the only species with moral agency: the ability to judge right from wrong and the capacity to act accordingly, regardless of adversity. This combination of morality and striving is not just a useful coping strategy; it is what defines us as human beings. It is what we mean when we talk of human dignity, of the human spirit or simply humanity. In the last century we so valued these qualities that 
we came together as a species to enshrine them as inalienable rights and commit their protection to international law.

And yet sixty years later we are self-harming on an industrial scale. The wealthiest $20 \%$ of us are consuming in a way that is destroying our bodies, our communities and our planet, and the global economic system is energetically encouraging the other $80 \%$ to follow suit. The cause of our predicament is that the most important, but least recognised, victim of our consumerism is the very humanity the UN set out to protect. We know what we are doing is wrong, but we continue doing it. Instead of rebelling against the marketing pressure to conform, we collaborate with it. This is causing us physical, mental and, most profoundly, spiritual harm. As Swedish essayist Sven Linquivst argues: 'You already know enough. So do I. It is not knowledge we lack. What is missing is the courage to understand what we know and to draw conclusions' (Linquivst (2002). Social marketing has a vital role to play in helping us find the courage, the sense of purpose, the spiritual strength to draw our own conclusions and take appropriate action; to move from being passive consumers to become active citizens - or, as Camus might express it, to become rebels with a cause.

\section{References}

Anderson P, de Bruijn A, Angus K, Gordon R, Hastings G. (2009) Impact of alcohol advertising and media exposure on adolescent alcohol use: a systematic review of longitudinal studies. Alcohol Alcoholism;44:229-43.

Bradshaw, T. (2011) 'Facebook Strikes Diageo Advertising Deal' in Financial Times, 8 September 20, http://www.ft.com/intl/cms/s/2/d044ea24-e203-e0-995-0044feabdc0.html\#axzzirtgC581

Bukowski C. (1996). The Laughing Heart. In: Betting on the Muse: Poems and Stories. Santa Rosa, CA: Black Sparrow Press. ISBN: 1-574-23001-8.

Cairns G, Angus K, Hastings G. (2009) The extent, nature and effects of food promotion to children: a review of the evidence to December 2008. WHO.

Camus A (2005) L'Homme Révolté, folio essais ISBN 978-2-07-032302-9 Espagne p8

Codina, V. (1985). Teología de la liberación y teología oriental: una aproximación. Revista

latinoamericana de teología (1985), vol. 2, no. 5, p. 147-170.

CRUK (2016) https://www.youtube.com/watch?v=a9KSaUueok \&

https://www.youtube.com/watch?v=0v|KmlUOx-Y

Dante Alighieri The Devine Comedy Canto 26

Donnely Jack (1985) The concept of human rights Croom Helm pp 3 and 33

Express (2016) http://www.express.co.uk/finance/personalfinance/468092/Loyalty-cards-TescoClubcard-V-Sainsbury-s-Nectar-card

Farid at din Attar (1974) The conference of the birds, Translated by C S Nott Routledge \& Kegan Paul

Farrelly MC, Healton CG, Davis KC, Messeri P, Hersey JC, Haviland ML (2002). Getting to the truth: evaluating national tobacco countermarketing campaigns. American Journal of Public Health, 92(6): 90-907.

Foley M (2008) The Age of Absurdity: Why Modern Life makes it Hard to be Happy Simon \& Schuster p74

Foley Ibid p73

WHO (2016) http://apps.who.int/gho/data/view.main.CODREG6EURV?lang=en 
Hastings G (2015), Public health and the value of disobedience, Public Health, http://dx.doi.org/10.1016/j.puhe.2015.03.010

Henley, W E (1849-1903) Invictus

Huxley A (97) the Devils of Loudon Chatto and Windus, London p 36

Laudato $\mathrm{Si}$, (2015) http://w2.vatican.va/content/francesco/en/encyclicals/documents/papafrancesco 2050524 enciclica-laudato-si.html p9

Levi $\mathrm{P}$ (1979) If this is a man Penguin books p47

Levi P op cit p119

Linquivst S (2002) Exterminate All The Brutes. The New Press. 179 pp

Louis C.K. (2016) http://www.thatvideosite.com/v/94

Lovato C, Linn G, Stead LF, Best A. (2003) Impact of tobacco advertising and promotion on increasing adolescent smoking behaviours. Cochrane Database Syst Rev;4:CD003439.

Morozov E (2013) To Save Everything Click Here, Allen Lane

Morozov E op cit p337

Pupavac V (2002) The International Children's Rights Regime, in Rethinking Human Rights Chandler D (ed) $p 72$

Sandel M (2013) What Money Can't Buy: The Moral Limits of Markets, New York Farrar, Strauss and Giroux, p 113

Smith R (2002) Learning from the abolitionists, the first social Movement $B M J ; 345$ :e830 doi

Smith R Op cit; p3 Evidence from a slave-ship doctor used in abolitionist leaflets

The Guardian (2016) https://www.theguardian.com/money/2016/jan/04/rise-consumer-borrowingfastest-pre-crisis-levels-bank-of-england-boe

The Guardian (2016) Editorial 02/09

WARC (2016) File: 20409_CocoCola_Euromonitor.pdf downloaded from www.warc.com

WMO (2016) http://public.wmo.int/en/media/press-release/globally-averaged-co2-levels-reach400-parts-million-205 


\title{
Rebels with a Cause: \\ The Spiritual Dimension of Social Marketing
}

\author{
Professor Gerard Hastings \\ The Institute for Social Marketing \\ University of Stirling, the Open University \\ and L'École des Hautes Etudes en Santé Publique \\ Stirling FK9 4LA \\ SCOTLAND
}




\section{Approach: Conceptual}

Findings: The greatest problems humankind faces, from NCD epidemics to global warming, are selfinflicted. We are voluntarily drinking the sugar sweetened beverages and driving the SUVs which threaten our health and our planet. It need not be so. Historical experience and two millennia of thinking show we are capable of better. We all have within us the moral agency to make the right choice even when it is the difficult one; we just have to reconnect with it. Indeed, it is this capacity and desire "to follow after wisdom and virtue", to rebel against injustice and malignancy, that makes us human and cements our collective identity. In the last century this realisation was focused by the terrible events of World War II and resulted in the formation of the United Nations and the Universal Declaration of Human Rights.

Originality/value: This paper argues that these ideas of agency, morality and rights have fundamental implications for social marketing. We have to move beyond mere behaviour change and start thinking about people in the round - body, mind and spirit. Our job involves more than giving diets a healthy nudge or making the ecological option easy, fun and popular; we have to foster and encourage the innate human drive to think critically and act accordingly. We are not here to edit choice but to facilitate personal growth and social progress.

\section{Introduction: self-harm on an industrial scale}

In the WHO European region $88 \%$ of deaths are now caused by non-communicable diseases such as diabetes, cancer and heart disease (WHO 2016). In the public health literature, these illnesses have become known as 'industrial epidemics', because they are driven by commerce, and specifically the overbearing marketing of alcohol, tobacco and highly processed foods. Furthermore there is compelling evidence that marketing does have exactly this kind of morbid power, especially over young people (Lovato et al 2003, Anderson et al 2009, Cairns et al 2009).

However an alternative conception of what is happening is that this carnage is self-inflicted; we are damaging and killing ourselves with our own consumption behaviour. Notwithstanding Coke's $\$ 3.3$ billion annual adspend (WARC 2016), we are not forced to drink its sugary beverages; Diageo's multimillion pound link-up with Facebook (Bradshaw 2011) does not prevent us from saying no to alcopops. Yes there is a massive power imbalance, and yes such unhealthy marketing needs to be contained, but nonetheless we do have a choice. We are capable of thinking for ourselves. And yet it seems we are happy to accept our fate without demur and collaborate in our own destruction.

Our lemming-like tendencies extend beyond lifestyle diseases; we are collaborating in the destruction of our communities with equal enthusiasm. It is easy to blame big box retailers for stifling the social capital of small shops or the car industry for our choked and polluting roads, but their success is completely dependent on our patronage. This we enthusiastically provide; we don't just shop at Tesco and Walmart, we willingly indenture ourselves with their loyalty schemes. Tesco's Club card programme, for example has over 16 million active members in the UK; its rival Sainsbury has over 19 million (Express 2016). The dictionary definition of loyalty is "a feeling of devotion, duty, or 
attachment to somebody"; it is unnerving that we use such a word to describe our relationship with a multinational corporation. Nor do SUVs drive themselves. We have freely bought into the conceit that we need a ton of metal with the technical capacity to cross the Sahara to get us a few hundred metres to the object of our retail devotion. Our behaviour doesn't even make economic sense: we willingly get ourselves into debt in our haste to kowtow to our materialist emperors (Guardian 2016).

Our self-harming collaboration takes its most troubling form with anthropomorphic climate change. This has been dubbed a 'wicked problem' because of its apparent complexity. But in at least one sense it is actually very simple. Anthropomorphic, of course, means caused by humans; in other words us. In particular, those of us who are in the wealthiest $20 \%$ of the world's population whose shopping behaviour is so utterly unsustainable. Planetary degradation is, in reality, just another lifestyle illness; one more symptom of our unthinking collaboration, our perpetual adoption of the line of least resistance. As the environmentalist George Monbiot observes "We'd never dream of killing gorillas or sharks, but let others do it: extinction is the bycatch of consumerism". We manage to live comfortably with these double standards; he continues: "it's not ignorance that's wiping out so many species: it's our naked hypocrisy". We also manage to live comfortably with planetary degradation; a week after Monbiot filed his piece, the World Meteorological Organisation's (WMO) annual greenhouse gas bulletin revealed that "globally averaged concentration of carbon dioxide in the atmosphere" had "reached the symbolic and significant milestone of 400 parts per million for the first time". This, the UN body warned, marked "the start of a new era of climate reality" (WMO 2016). A reality we blithely deny as we continue our consumerist collaboration.

\section{Learning from the abolitionists}

It was not always so. William Wilberforce is often given the credit for the abolition of slavery, and there is no doubt that he and his colleagues do deserve a lot of credit. However the true heroes of the hour were people like us; ordinary citizens. Wilberforce himself recognised that nothing would be achieved without public support and in his famous speech to the House of Commons he called on the British citizenry with the ringing phrase: "we ought all to plead guilty" (Smith 2012), invoking both the moral and practical imperative of grass roots involvement.

The challenge was truly daunting. In 1787 , when the campaign began, there were actually more slaves than free people in the world. Furthermore, slavery represented massive economic interests: in the UK with its growing Empire, nearly 2\% of Gross Domestic Product was at stake. Wilberforce and his eight colleagues used many techniques modern social marketers would recognise. They had a clear vision, 'drawing connections between the near and the distant', for what they wanted to achieve. This was converted into achievable, pragmatic objectives - the cessation of trading rather than complete emancipation (the former would inevitably lead to the latter anyway). They engaged in classic strategic planning based on careful market research, a detailed situation analysis identifying key stakeholders and competitors and shrewd tactical deliberation. They recognised that success would take time (eight of the nine originators were dead by the time their aim was accomplished) and hence progress needed continuous monitoring to inform adjustments to the strategy. Mass media communications were also deployed to great effect, and in the best social marketing traditions, they weren't afraid to use highly emotional appeals (Fig 1). 


\section{Figure 1: Anti-slavery Advertising}

"A woman was one day brought to us to be sold; she came with a child in her arms. The captain refused to purchase her on that account, not wishing to be plagued with a child on board; in consequence of that she was taken back to the shore. On the following morning, however, she was again brought to us, but without the child, and she was apparently in great sorrow. The black trader who brought her on board said that the child had been killed in the night to accommodate us in the sale." (Smith op cit)

But the most important factor in their success was the vital role played by ordinary people. Abolition movements were established in towns across the country. These encouraged critical thinking drawing "the dramatic, direct connection between British daily life and that of slaves". Tea, that quintessentially British symbol of civilised domesticity, became "the blood stained beverage". This critical thinking was converted into direct action - fundraising, letter writing to political representatives, petitions, protests, fliers, public meetings and boycotts of sugar and tea. The result was an unstoppable force and, despite the special pleading and massive commercial interests, the government simply had to move. A leading newspaper of the time expressed it trenchantly: "the sense of the people has pressed abolition on our rulers".

\section{Moral agency}

The abolitionists reveal something fundamental about human beings: we have the ability to think through the implications of our actions, to distinguish between right and wrong and to act accordingly. We can plan for the future; forgo benefits today for rewards tomorrow. We can also think of others. We are capable of altruism, of putting ourselves in harm's way for the benefit of our fellow beings. Parents habitually make sacrifices for their children; soldiers are honoured for risking their own safety to protect their comrades. As a recent newspaper editorial argued, these are uniquely human qualities: "We are the only species capable of reflecting on our impact. We have moral agency. We can foresee the likely consequences of our actions, consider them, and then make choices" (Guardian 2016). We are, in the words of the poet, the masters of our fate and the captains of our soul (Henley).

Sadly, good parents and heroic warriors notwithstanding, this moral agency seems to be in short supply. Lifestyle diseases, over consumption and especially our disregard for the environment betray a disturbing lack of principled analysis, consideration for others or thought for the future. The leader continues: "In relation to the environment, these choices have frequently been wrong and show little sign of being right in time to save us from very large and damaging climate change."

This suggests that a crucial task for social marketing is to reawaken our moral agency. Perhaps instead of addressing 'wicked problems' like obesity or global warming with complex systems thinking, accompanied by daunting Foresight diagrams, we should be looking internally to the human qualities that enable us to feel as well as think, to consider morality in addition to convenience and to do the right thing not because it is easy, fun and popular but because it is right.

Indeed if we consider for a moment the complexity of the relationship between behaviour and welfare, anything else seems naïve. Yes we know of the link between tobacco and lung cancer, so encouraging people to avoid or quit smoking makes obvious sense. The same type of evidence and thinking applies for alcohol and ultra-processed foods. We can stretch this further to energy efficiency, recycling, public transport... but life is so much more than a collection of behaviours. The forces which make us happy, or feel fulfilled or give us purpose cannot be identified and proven effective by an RCT or delivered by an intervention. To a large extent they are not external at all, but lie inside each of us. 
In this sense moral agency becomes much more than a handy strategic tool. When Pandora let human vices escape her box, moral agency was the driving force of the hope that struggled out in their wake. It tells us something about the nature of our humanity. Nowhere is this more apparent than in the consideration of climate change, because it requires us to think about the future; about the world after our deaths; about a time and place where personal gain is no longer possible, and more profound issues assert themselves. The recent Papal Encyclical spells out the implications: "When we ask ourselves what kind of world we want to leave behind, we think in the first place of its general direction, its meaning and its values.... if those issues are courageously faced, we are led inexorably to ask other pointed questions. What is the purpose of our life in this world? Why are we here? What is the goal of our work and all our efforts? What need does the earth have of us? It is no longer enough, then, simply to state that we should be concerned for future generations. We need to see that what is at stake is our own dignity. Leaving an inhabitable planet to future generations is, first and foremost, up to us" (Laudato Si, 2015).

The word dignity is crucial here. The dictionary links it to self-respect and a sense of personal pride. Thus it begins to explain why agency is so important; it suggests a fundamental human need to exercise judgement and make choices, even when these are difficult. The key benefit of doing this is self-enhancement: we learn how to make challenging decisions, with practice we get better at doing it and as a result we become more rounded human beings. In Charles Bukowski's (1996) words "the more you learn to do it the more light there will be".

Farid at din Attar (1974), an eminent Sufi scholar came to the same conclusion almost a millennium ago. Figure 2 summarises his epic poem the Conference of the Birds which tells of our hunt for spiritual purpose, a sense of meaning beyond the everyday priorities that tend to dominate our lives.

Figure 2: The Conference of the Birds

The birds of the air were anxious; they felt in urgent need of advice and leadership. A great conference was organised where they came together to discuss what might be done. The Hoopoe spoke up and persuaded the gathering that they needed to go in search of the Simurgh or spiritual leader, to provide them with the direction they lacked. After much debate and multiple attempts by different birds to avoid going on what would be an arduous journey, the quest got underway. It took many difficult years and involved crossing the seven valleys - of searching, love, understanding, friendship, unity, amazement, and death - each presenting its own challenges and lessons. As the pilgrimage proceeded, many birds abandoned the journey or were overcome by the ordeals they encountered. Eventually, now depleted to band of just thirty, they arrived at a marvellous palace, which, the Hoopoe explained, was the home of the Simurgh. At first the palace guard would not let what had become a raggedy and disreputable looking gang enter the great mansion; but after a struggle they were admitted. Inside they searched everywhere for the Simurgh but the place was empty. All they found was wall after wall lined with mirrors of every size and shape.

It was in these that they at last caught sight of their spiritual leaders.

Like Bukowski he is advising us to look inwards. Such introspection undoubtedly brings with it the need for effort: it is arduous and it is 'up to us'. It is also an endless task; "the search for meaning is itself the meaning" Foley M (2010). But, it is essential to our humanity: "the man who lives and does not strive is lost" (ibid). It also suggests a more adult and humane approach to social progress than the thoughtless behaviour change orchestrated by nudge. 


\section{If this is a Man}

If our behaviour is not simply a function of external stimulus, let alone well-meaning interventions, but also a product of our internal qualities, we have to understand more about what these are, about what it is to be human. Primo Levi, the holocaust survivor, saw Auschwitz as an appalling but brutally effective experiment which was, inadvertently, capable of answering this question. In his book, If this is a Man, he explains how the Nazis set about systematically dehumanising their victims so as to make it easier to mistreat and murder them. Life in the camps was deliberately designed to be as unbearable as possible so prisoners were pushed to behave selfishly, even brutally - to emulate their oppressors and abandon their humanity - in order simply to survive. And they were utterly defenceless: "we are slaves, deprived of every right, exposed to every insult, condemned to certain death..." Never had external stimuli been more destructive or debilitating, yet Levi maintains that the prisoners still possessed a vital level of agency: "...but we still possess one power, and we must defend it with all our strength for it is the last - the power to refuse our consent" (Levi P 1979). However desperate our plight, we have an inner room which we can and must save from violation. This is our dignity. For Levi it is what makes us human.

Later in the book he takes this thinking a step further, using Dante's Divine Comedy. In his poem, Dante invokes Vergil and the epic journey of Ulysses. Specifically Levi quotes a speech the Greek hero made to embolden his men for the next stage of their voyage.

\section{"Look inward, to your origins. For brutish ignorance Your mettle was not made; you were made human To follow after wisdom and virtue" (Dante)}

The words have a profound effect on his men and they become more than willing to continue their "foolhardy journey beyond the Pillars of Hercules" (symbolising the dangerous unknown) (Levi, op cit) because it offered the promise of wisdom. The power of the words was not a tribute to Ulysses' oratory, but confirmation that he was appealing to their irreducible humanity. Beings of their - our mettle could do no other. Thus the same two principles emerge: our lot as human beings is to be seekers after wisdom and virtue; this quest will not be easy - it requires effort, hard work, the overcoming of adversity. Dante understood adversity as well as did Ulysses and his crew; he wrote his Divine Comedy as an exile on the run from the powerful political factions of medieval Italy.

But living in a consumer society like ours obscures the benefits of striving. Obstacles become new product development opportunities and shopping the means of assuaging them. It is difficult to embrace toil and adversity when the dominant narrative is of customer service and perpetual satisfaction. Critical social marketing has a key role to play in deconstructing this damaging narrative.

\section{Transcendence}

Aldous Huxley extends this thinking when he talks of an innate human drive for 'self-transcendence', adding a rather chilling reminder that this is an immensely powerful urge because humankind's selfknowledge - and particularly the realisation of our own mortality - underpins a compulsion "to escape from the tormenting consciousness of being merely ourselves" (Huxley 1971). We are continually seeking a sense of purpose to our lives. But again he warns that it is dependent on adversity; there are no simple solutions: self-transcendence takes hard work. Consequently, as Huxley goes on to discuss, this drive is extraordinarily susceptible to corruption. We are all reluctant "to take the hard, ascending way" and instead opt for "bogus liberation". Marketing, with its excellent, 'because you're 
worth it', service, with its siren call to consume ourselves to happiness, is bogus liberation writ large. Social marketing risks falling into the trap of copying this infantilising approach when it resorts to spoon-feeding and nudging.

More recent writers in the field of technology also express concerns about what they term 'solutionism' (Morozov 2013); IT being used to solve problems for us that we don't even know exist. This inures us from the consequences of our acts: my smart phone provides a service that my parents could barely have imagined and in the process suppresses my nagging concerns about the conflict minerals it contains. It also spoils us; we very rapidly demand more and more functionality. Comedian Louis C.K. (2016) does a riff on how quickly we take remarkable innovations - from human flight to mobile phones - for granted. He concludes, with brutal honesty: 'we live in an amazing, amazing world and it's wasted on the crappiest generation of, just, spoiled idiots that don't care'. Morozov adds a third corrosive impact of solutionism: we learn to react rather than respond: 'treating issues as puzzles to which there is a solution, rather than problems to which there may be a response' (Morozov op cit). Michael Sandel (2013) reminds us of the long term dangers: "altruism, generosity, solidarity and civic spirit are not like commodities that are depleted with use. They are more like muscles that develop and grow stronger with exercise."

And so the individual can be seen as the indivisible unit and motive force of social change. A key task of social marketing is to stimulate and empower this force. This takes us much deeper than mere behaviour change. It calls for humility to admit we do not have all the answers; a recognition that solutionism can do more harm than good; that we should not be seeking obedience but encouraging disobedience (Hastings 2015). The self-destructive collaboration that is driving both noncommunicable disease and global warming is most vulnerable to critical awareness. For social marketers it raises the question of whether we should be concerned with behaviour or with people. Dante, Levi and Huxley would put the question more bluntly: is social marketing here to enhance our humanity or just further encourage its decline?

\section{Collective agency and human rights}

Thus a focus on the individual is not to deny the importance of the collective, but to reinforce it. Once we start to look critically at our world, it pushes us to consider others. If I am unhappy with the effects the system is having on me, at the same instant I come to recognise that others are also suffering. If my father dies of pneumoconiosis I begin to empathise with the fate of other coal miners or if a car knocks me off my bike the benefits of cycle paths for all become more apparent. French writer Albert Camus is precise about this, arguing that whilst our suffering in the face of a world that is difficult to understand and often unsympathetic (in his words 'absurd') is individual, once we begin to criticise and act on these criticisms - that is to rebel - it immediately becomes collective. The stimulus to mitigate our individual hardship connects us with the humanity of others; the individual harm becomes a shared plague. Much as Descartes argued that our desire and ability to think demonstrates our individual existence, so Camus sees our desire and ability to rebel as proof of our collective existence. 'I think therefore I am' is joined by 'I rebel therefore we are' (Camus 2015).

Camus and Levi were writing in the immediate aftermath of the Second World War; a time when it was recognised that there had been a profound failure of moral agency and there was a desperate hunger to prevent any repetition of the holocaust and its related horrors. In this context, the idea that all human beings have the same fundamental qualities, share an "inherent dignity", and are equal "members of the human family" had powerful resonance. The idea grew that the protection and 
nurturing of these qualities, and recognition of them as inalienable moral and legal rights was the only progressive way forward. Under the auspices of the newly formed United Nations this resulted in The Universal Declaration of Human Rights.

Its implications for social marketing are fundamental. Take for example the Convention on the Rights of the Child (Fig 3) which is the most widely-ratified international treaty in history. It enshrines in international law "the right of the child to the enjoyment of the highest attainable standard of health", that for any government "the best interests of the child shall be a primary consideration" and requiring administrations "to ensure the child such protection and care as is necessary for his or her well-being, ....and, to this end, shall take all appropriate legislative and administrative measures". This means that measures social marketers would support, such as controls on harmful marketing or minimum unit pricing are not just evidence-based actions which governments can be encouraged to take, they are legal obligations which they have to take. It also challenges treasured assumptions. The idea that interventions necessarily threaten freedom, for example, as the Nuffield Ladder of Interventions (Nuffield Council on Bioethics 2007) presupposes, become much more questionable. The supposedly oppressive influence of the 'nanny state' is likewise undermined when we consider that children have a right to protective legislation. Indeed it completely inverts the argument, suggesting that the overbearing nanny is actually the unhealthy marketer, not the legislator, and she is a nanny from hell.

\begin{tabular}{|l|} 
Figure 3: Convention on the Rights of the Child (extract) \\
Ratified by the UN General Assembly 20th November 1989
\end{tabular}

\section{Article 24}

1. States Parties recognize the right of the child to the enjoyment of the highest attainable standard of health and to facilities for the treatment of illness and rehabilitation of health. States Parties shall strive to ensure that no child is deprived of his or her right of access to such health care services.

2. States Parties shall pursue full implementation of this right and, in particular, shall take appropriate measures:

a) To diminish infant and child mortality;

b) To ensure the provision of necessary medical assistance and health care to all children with emphasis on the development of primary health care;

c) To combat disease and malnutrition, including within the framework of primary health care, through, inter alia, the application of readily available technology and through the provision of adequate nutritious foods and clean drinking-water, taking into consideration the dangers and risks of environmental pollution;

d) To ensure appropriate pre-natal and post-natal health care for mothers;

e) To ensure that all segments of society, in particular parents and children, are informed, have access to education and are supported in the use of basic knowledge of child health and nutrition, the advantages of breastfeeding, hygiene and environmental sanitation and the prevention of accidents;

f) To develop preventive health care, guidance for parents and family planning education and services. 
But the implications of human rights for social marketing take us beyond advocacy. They reinforce the importance of moral agency: "the nature that underlies natural or human rights is the moral nature of a human being" and they emphasise the idea of human potential "human rights are less about the way people are than about what they might become" (Donnelly 1985). Human rights law can provide an environment in which this potential can be fulfilled, but in and of itself will not stimulate people to take up the resulting opportunities for personal growth. Social marketing has a vital role to play in providing this stimulus; in providing society with a critical and aware citizenry that will make the most of its hard-earned and mandated human rights. Young people can, for example, be encouraged to exert their rights to protection from tobacco industry predation, as they were with the American Legacy's Truth Campaign (Farrelly et al 2002), and more recently in Cancer Research UK's "Smoke This" and "Make Them Pay" digital initiatives (CRUK 2016).

The prize for doing this is indeed worth the winning: "...human development is possible only through comprehensive human action coordinated by human rights". However it carries with it risks as well benefits: "The 'human nature' that underlies human rights is quintessentially human, full of frailties but also fraught with the possibility of the greatest glory. Human rights are a practical political institution for widely realising these higher potentials..." (Donnelly op cit). If social marketers are going to move from micromanaging specific behaviours to empowering people, they have to be prepared to let go control and take chances. This is not as radical as it might sound; arguably it is just the natural endpoint for the social marketing commitment to client orientation. If we listen to and respect the people we work with to the extent that we claim, we should have the confidence to trust them with finding their own solutions. Or as the liberation theologist argued: "it is not about giving them a fish; it is not even about teaching them to fish - it is about recognising their ownership of the river" (Codina 1985).

Conversely popular engagement in this field is also an important safety measure. Without it, human rights legislation risks becoming no more than pious sentiment, or worse doing actual harm. Vanessa Pupavac (2002), for example explains how over-zealous application by adults of the child's right to safety has dangerously constrained play, reducing school playtimes and even eliminating unsupervised play altogether: "Panics over strangers, concerns about environmental dangers, potential litigation over accidents (however remote) and fears over bullying are all leading to a constriction of children's play. The expanded meaning of protecting children from harm has required such all-encompassing dimensions that the eradication of risk effectively entails the elimination of unsupervised play". The negative consequences included isolation, obesity and mental illness. The way to prevent this unintended harm is to encourage everyone to join the debate; social marketers, along with others interested in progressive social change, need to embrace this challenge.

\section{Conclusion}

We are the only species with moral agency: the ability to judge right from wrong and the capacity to act accordingly, regardless of adversity. This combination of morality and striving is not just a useful coping strategy; it is what defines us as human beings. It is what we mean when we talk of human dignity, of the human spirit or simply humanity. In the last century we so valued these qualities that we came together as a species to enshrine them as inalienable rights and commit their protection to international law.

And yet sixty years later we are self-harming on an industrial scale. The wealthiest $20 \%$ of us are consuming in a way that is destroying our bodies, our communities and our planet, and the global 
economic system is energetically encouraging the other $80 \%$ to follow suit. The cause of our predicament is that the most important, but least recognised, victim of our consumerism is the very humanity the UN set out to protect. We know what we are doing is wrong, but we continue doing it. Instead of rebelling against the marketing pressure to conform, we collaborate with it. This is causing us physical, mental and, most profoundly, spiritual harm. As Swedish essayist Sven Linquivst argues: 'You already know enough. So do I. It is not knowledge we lack. What is missing is the courage to understand what we know and to draw conclusions' (Linquivst (2002). Social marketing has a vital role to play in helping us find the courage, the sense of purpose, the spiritual strength to draw our own conclusions and take appropriate action; to move from being passive consumers to become active citizens - or, as Camus might express it, to become rebels with a cause.

\section{References}

Anderson P, de Bruijn A, Angus K, Gordon R, Hastings G. (2009) Impact of alcohol advertising and media exposure on adolescent alcohol use: a systematic review of longitudinal studies. Alcohol Alcoholism;44:229-43.

Bradshaw, T. (2011) 'Facebook Strikes Diageo Advertising Deal' in Financial Times, 8 September 20, http://www.ft.com/intl/cms/s/2/d044ea24-e203-e0-995-0044feabdc0.html\#axzzirtgC581

Bukowski C. (1996). The Laughing Heart. In: Betting on the Muse: Poems and Stories. Santa Rosa, CA: Black Sparrow Press. ISBN: 1-574-23001-8.

Cairns G, Angus K, Hastings G. (2009) The extent, nature and effects of food promotion to children: a review of the evidence to December 2008. WHO.

Camus A (2005) L'Homme Révolté, folio essais ISBN 978-2-07-032302-9 Espagne p8

Codina, V. (1985). Teología de la liberación y teología oriental: una aproximación. Revista latinoamericana de teología (1985), vol. 2, no. 5, p. 147-170.

CRUK (2016) https://www.youtube.com/watch?v=a9KSaUueok \& https://www.youtube.com/watch?v=0vIKmlUOx-Y

Dante Alighieri The Devine Comedy Canto 26

Donnely Jack (1985) The concept of human rights Croom Helm pp 3 and 33

Express (2016) http://www.express.co.uk/finance/personalfinance/468092/Loyalty-cards-TescoClubcard-V-Sainsbury-s-Nectar-card

Farid at din Attar (1974) The conference of the birds, Translated by C S Nott Routledge \& Kegan Paul

Farrelly MC, Healton CG, Davis KC, Messeri P, Hersey JC, Haviland ML (2002). Getting to the truth: evaluating national tobacco countermarketing campaigns. American Journal of Public Health, 92(6): 90-907.

Foley M (2008) The Age of Absurdity: Why Modern Life makes it Hard to be Happy Simon \& Schuster p74

Foley Ibid p73

WHO (2016) http://apps.who.int/gho/data/view.main.CODREG6EURV?lang=en

Hastings $G$ (2015), Public health and the value of disobedience, Public Health, http://dx.doi.org/10.1016/i.puhe.2015.03.010

Henley, W E (1849-1903) Invictus

Huxley A (97) the Devils of Loudon Chatto and Windus, London p 36 
Laudato Si, (2015) http://w2.vatican.va/content/francesco/en/encyclicals/documents/papafrancesco 2050524 enciclica-laudato-si.html p9

Levi P (1979) If this is a man Penguin books p47

Levi P op cit p119

Linquivst S (2002) Exterminate All The Brutes. The New Press. 179 pp

Louis C.K. (2016) http://www.thatvideosite.com/v/94

Lovato C, Linn G, Stead LF, Best A. (2003) Impact of tobacco advertising and promotion on increasing adolescent smoking behaviours. Cochrane Database Syst Rev;4:CD003439.

Morozov E (2013) To Save Everything Click Here, Allen Lane

Morozov E op cit p337

Pupavac V (2002) The International Children's Rights Regime, in Rethinking Human Rights Chandler D (ed) $p 72$

Sandel M (2013) What Money Can't Buy: The Moral Limits of Markets, New York Farrar, Strauss and Giroux, p 113

Smith R (2002) Learning from the abolitionists, the first social Movement BMJ;345:e830 doi

Smith R Op cit; p3 Evidence from a slave-ship doctor used in abolitionist leaflets

The Guardian (2016) https://www.theguardian.com/money/2016/jan/04/rise-consumer-borrowingfastest-pre-crisis-levels-bank-of-england-boe

The Guardian (2016) Editorial 02/09

WARC (2016) File: 20409_CocoCola_Euromonitor.pdf downloaded from www.warc.com

WMO (2016) http://public.wmo.int/en/media/press-release/globally-averaged-co2-levels-reach-

400-parts-million-205 